\title{
AUTHOR/TITLE INDEX TO VOLUME 3 (1983)
}

Calendar of Events

Caruso, N. and E. Caruso, TRAINER - a computer tutorial for end-users of database services: context, content, and results of use

Castonguay, D., A. Oikawa and R. Vézina, Information and communications technology serving the needs of Canada's museum curators and researchers

Dijkhuis, W., Eyes and hands: an examination of keyboards and screens

Fleck, D.R., Developing a self-training manual

Garvin, A.P., Re-use and re-packaging of information: the information intermediary viewpoint

Horlacher, E.: see Gunzenhäuser, R.

ISU Interview

Keenan, S., Re-use and re-packaging of information: the information worker's view

Line, M.B., The future of libraries in the information transfer chain

Maurer, H., New developments in videotex and their implications for computer aided instruction (CAI)

Oikawa, A.: see Castonguay, D.

Prentice, A.E., On-line training: the role of schools of library and information science 
Reviews

Rosenblith, W.A., Scientific information and societal change

Sugawara, H. and Y. Tateno, Advancement of a National Information System of Laboratory Organisms (NISLO)

Tateno, Y.: see Sugawara, H.

Tschudi, C.M., Educating and/or training the online searcher

Vézina, R.: see Castonguay, D.

Ware, W.H., The information commodity market

Wolpert, S.A., A command language for the executive
$73-74,75-76$

$153-158$

49-58

179-183

159-166

261-272 